\title{
電極表面の第一原理計算
}

\author{
山本 雅 博 \\ 京都大学大学院工学研究科物質エネルギー化学専攻 —615-8510 京都府京都市西京区京都大学桂
}

(2003 年 10 月 3 日受理)

\section{First-principles Calculation of Electrode Surface}

\author{
Masahiro Yамамото \\ Department of Energy and Hydrocarbon Chemistry, Graduate School of Engineering, Kyoto University \\ Nishikyo-ku, Kyoto 615-8510
}

(Received October 3, 2003)

\begin{abstract}
Since the electrode interface phenomena have multiscale nature in space and time, the multiscale model from quantum to continuum level should be considered. In this article we describe the structure of the $\mathrm{Pt}(111) /$ dipolar liquid interface and the adsorption of sulfur on electrified $\mathrm{Au}(111)$ surface. The structure of the $\mathrm{Pt}(111)$ /dipolar liquid interface has been investigated by fully self-consistent combination of the first-principles calculation based on quantum mechanics for the metal and the reference hypernetted-chain (RHNC) theory for the liquid. The electronic density profile for the metal, density and orientational structure of liquid molecules, and electrostatic potential across the interface are discussed in detail. A dense layer of liquid molecules, which is ordered in terms of orientation, is formed near the metal surface, but this surface-induced structure extends about only three molecular diameters from the surface. This result is in agreement with the recent experimental observations. For $\mathrm{S}$ adsorption on electrified $\mathrm{Au}(111)$ surface the screening of the electron at metal surface and the change of the adsorption energy of sulfur are discussed briefly.
\end{abstract}

\section{1. 緒}

言

量子力学の基礎方程式から出発する第一原理計算は, 経験的パラメータのない計算であり, 表面・界面の構 造・物性を予測することが可能である。第一原理計算に よる金属・半導体表面の構造 - 吸着子との相互作用等に ついて表面科学の分野で多くの報告がなされてきだ。 しかしながら, 現代の最先端の理論である第一原理計算 を用いても電極表面での現象を理論的に取り扱うことは 未だ完全になされてないと言って良い。既に, いくつか のグループが金属|水溶液界面の系を, 第一原理計算 (full quantum) で理論的に解析した報告はあるが3〜6),

E-mail: masahiro@scl.kyoto-u.ac.jp

ただし，表面系では最近指摘されたように $\mathrm{Pt}(111)$ 面上の 一酸化炭素吸着サイトが実験結果と第一原理計算では一致し ない問題がある ${ }^{1,2)}$ 。密度汎関数理論で電子間の交換・相関 相互作用を近似しているところに根本の原因があるようだ が, 結合次数が変わるような系での計算には注意が必要であ ろう。
水溶液中に電解質のない帯電していない電極 | 純水界面 についての報告である。これらの解析では計算量が膨大 になるため, 十分に統計的平均が得られているのかも不 明である。

電極の理論的な取り扱いが困難な理由は, 1）電極材 料である金属・半導体界面の電子, 電極と吸着分子の結 合を量子力学的に取り扱う必要があること，2）室温で の溶媒を扱うために, 電極近傍の溶媒分子, 電解質イオ ンを量子力学的にあるいは経験的な分子間ポテンシャル を用いてモンテカルロ法や分子動力学法を用いて分子論 的に取り扱う必要があること，3）電気 2 重層の遮蔽長 さが電解質濃度が小さい場合には $\mu \mathrm{m}$ にまで到達するの で Poisson-Boltzmann 方程式等を用いた連続体モデルで 近似しなくてはならないことがある。それにはこれらの 理論をシームレスに接続するいわゆるマルチスケール理 論が必要であろう。Fig. 1 にマルチスケール理論の概念 図を示す。マルチスケール理論は, 現実の材料の物性は 電子の階層, 原子・分子の階層, 連続体レベルでの階層 


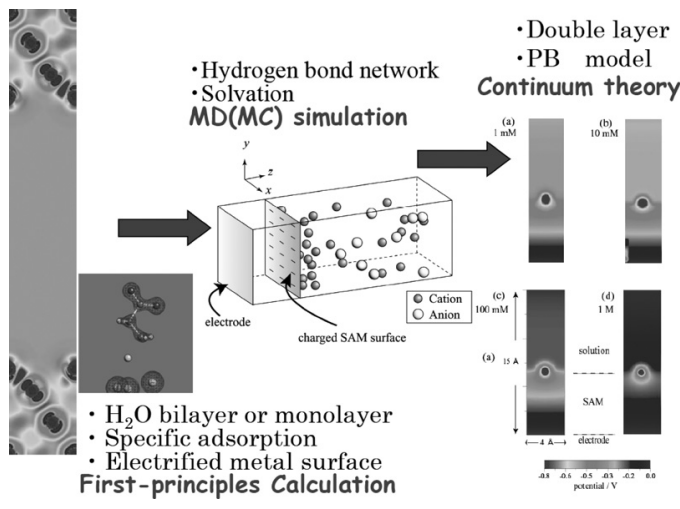

Fig. 1 Schematic diagram of multiscale theory for electrode surface.

すべてを考慮して初めて説明可能であるという観点に基 づいた理論である。それぞれの階層の理論を矛盾無く繋 ぐのは容易ではないが，電気化学系の場合はそれぞれの 階層で計算された静電ポテンシャルで自己無撞着的に慗 ぐのが最も単純な手法である。ただし, 溶液側で水分子 の電極への吸着やハライドの特異吸着等は電子レベルか ら解かないと正確には表せない。各階層での理論解析の 例として, Fig. 1 には, 電子の階層では $\mathrm{Au}(111)$ 面上 の硫黄の吸着と金上のメルカプトプロピオン酸（MPA） の吸着の第一原理計算による電子分布図, 原子・分子の 階層では末端カルボキシル基が解離した MPA 自己組織 化単分子膜上のモンテカルロシミュレーションによる電 気 2 重層の解析の模式図, 連続体レベルでの階層では, Poisson-Boltzmann 方程式による末端カルボキシル基が 解離した MPA 自己組織化単分子膜上の電気 2 重層の電 位分布の断面図を示した。

電極表面での酸化還元反応についてはバルク中でのイ オンの溶媒和の問題 (酸化還元電位の問題”), イオン と電極間の電子移動の問題（電子移動速度の問題 ${ }^{8}$ ) 等 さらに複雑な問題を含んでいるため第一原理計算による 取り扱いはほとんどなされていない。

電極界面の構造をマルチスケール理論で扱った例とし ては, ジェリウムモデルと積分方程式の結合理論 ${ }^{212}$, 水分子に分子擬ポテンシャル**を用いた Halley-Price ら の報告 $\left.{ }^{8}\right), \mathrm{Pt}(111)$ 面の第一原理計算と RHNC（reference hypernetted-chain）積分方程式論を自己無撞着に結合さ

** 通常の第一原理計算で用いる原子に対するノルム保存擬ポ テンシャル（またはウルトラソフト擬ポテンシャル）とは 異なり，水分子に対して擬ポテンシャルを構成する13)。静 電相互作用や分極，コア反発の効果は含まれるが，電極表 面で化学吸着する表面近傍の水分子に対してこのポテンシ ヤルを使う近似はおそらく正しくないだろう。
せた我々の報告 $\left.{ }^{14}, 15\right)$ ，3 次元 RISM（reference interaction site model）理論と $\mathrm{Cu}$ (100) 面の第一原理計算を組み合 わせた Kovalenko-平田の報告 ${ }^{16,17}$ がある。本文では, 我々 の研究結果と帯電した $\mathrm{Au}(111)$ 面上と硫黄原子の吸着 相互作用について報告する。

\section{2. 計 算 方 法}

固体表面の計算は，大別して LCAO（Linear Combination of Atomic Orbital）基底系での量子化学クラスター計 算と，平面波基底系を用いたスラブ周期格子系に対する 第一原理バンド計算がある。クラスターモデルは，全工 ネルギー・原子間力のクラスターサイズ依存性の問題や 電極表面が電場を遮蔽する効果を正確に計算できないの でここでは, 後者のスラブ周期境界条件を用いたバンド 計算の手法を用いた。計算は, ノルム保存擬ポテンシャ ル法を用い，電子の交換相関相互作用には，局所密度近 似（LDA）である Hedin-Lundqvist 型を用いた ${ }^{18)}$ 。原子 に局在化した d 電子をもつ白金を取り扱うために, 15 Ry までの運動エネルギーをもつ平面波に加えて原子に局在 する波動関数の Bloch 和の混合基底系を用いた ${ }^{19)}$ 。表面 の計算では, 逆格子空間内の irreducible Brollouin ゾーン 内の 18 個の点を用いた。

\section{3. 金属-液体界面の構造：積分方程式と第一原 理計算の結合の自己無撞着解}

近年，金属-液体界面の構造は，種々の分光法により その微視的な構造が明らかになっている ${ }^{20 \sim 26) 。 こ れ ら の ~}$ 結果を理解するために，第一原理計算のような信頼性の ある理論モデルを構築することは重要である。ここでは, $\mathrm{Pt}$ (111) 面の第一原理計算と双極子液体の積分方程式論 の結合の計算結果を述べる。

界面から無限に広がる溶液系を考慮できることに利点 があるため，我々は溶液側に積分方程式を用いた。通常 の computer simulation と異なり，積分方程式を用いた方 法は, 系の有限サイズの効果や不十分なモンテカルロ・ 分子動力学ステップ等の問題を考慮する必要がな

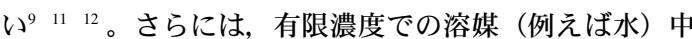
の電解質イオンを取り入れることも容易に可能であ る ${ }^{10}$ 。Bérard らは, 積分方程式論のひとつである reference hypernetted-chain（RHNC）理論を溶液側に適用し，金属 表面と接している水溶液電解質と極性溶液に対して自己

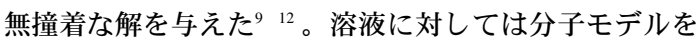
採用した精密な統計力学理論が用いられているのに対 し，金属に対しては金属イオンを一様な正電荷バックグ ラウンドとみなす jellium モデルを用いるのにとどまっ ていることに問題があった。 jellium モデルは, $r_{s}$ (Wigner- 
Seitz 半径) 值が約 2.5 以下で破綻する 27 ことが知られて いる。しかし， $r_{s}$ 值が小さい金属には, 白金 $\left(r_{s} \simeq 1.4\right)$ などの実用的に重要なものが多い。本研究は, 金属側を 経験的パラメータのない第一原理計算で行い, 金属側・ 溶液側を静電ポテンシャルで接続し, 完全に“selfconsistent” な数值解を得た。白金（111）面一極性溶液系 の電子密度, 溶液構造, 固液界面をよぎる静電ポテンシ ヤルを議論する。

我々の方法は Bérard らによる方法と基本的に同じで あるが，金属表面を第一原理計算で扱っていることに違 いがある。白金（111）面を 11 層持つ繰り返しスラブを 金属側の計算に用いた。金属 8 層分に相当する厚みをも つ非金属相(真空あるいは溶液)がそのスラブ間にある。 溶液側の積分方程式と結合して行ったポテンシャルの自 己無撞着計算より, ここで用いたスラブとその非金属領 域の厚みは十分な厚みを持つ。溶液側の計算では RHNC 理論が使われているが, 双極子液体が半無限のスラブと 相互作用するとして計算した。液体分子は直径 $d_{s}=0.28$ $\mathrm{nm}$ をもつ剛体球で, 剛体球の中心に双極子 $\mu$ をもつと した（以後液体分子を溶媒分子と呼ぶ）。溶媒分子に対 して金属は剛体壁として㗢くと仮定した。その位置は表 面の白金原子から溶媒分子の中心まで $0.20 \mathrm{~nm}$ とした。 これは Pt(111)/water（0.1 M KOH solution）in-situ X 線 散乱の実験に基づくものである ${ }^{22)}$ 。その実験では, いか なる電位でも表面再構成しないこと, 水分子の層は密度 0.8/Pt atom で表面白金原子から約 $0.2 \mathrm{~nm}$ のところにあ ると報告している。

金属は，表面近傍の液体を分極させるのに十分な強い 電場を与える。液体は逆に金属をポテンシャル（溶媒分 子の配置と配向性に依存する）を通して分極させる。静 電場を通した 2 相間の相互作用のみを考え, 相間の電 荷・物質の移動はないと仮定した。

まず，白金表面 (真空) の第一原理計算を行った。解 くべき Kohn-Sham 方程式は

$$
\begin{aligned}
& {\left[-\frac{\hbar^{2}}{2 m} \nabla^{2}+\sum_{\mathbf{R} \boldsymbol{r}_{j}} \hat{v}_{\mathrm{ion}}^{\mathrm{ps}}\left(\left|\mathbf{r}-\mathbf{R}-\mathbf{r}_{j}\right|\right)+v_{\mathrm{H}}(\mathbf{r})\right.} \\
& \left.+v_{\mathrm{xc}}[\rho(\mathbf{r})]+v_{\mathrm{dip}}(z)\right] \psi_{n \mathbf{k}}(\mathbf{r})=\varepsilon_{n \mathbf{k}} \psi_{n \mathbf{k}}(\mathbf{r})
\end{aligned}
$$

ここで, $n \mathbf{k}$ は第一ブリルアンゾーン内の $\mathbf{k}$ 点の $n$ 番目 のバンド指標である。 $v_{\mathrm{H}}(\mathbf{r})$ は

$$
v_{\mathrm{H}}(\mathbf{r})=\int d \mathbf{r}^{\prime} \frac{\rho\left(\mathbf{r}^{\prime}\right)}{\left|\mathbf{r}-\mathbf{r}^{\prime}\right|}
$$

で, 電子密度は $n \mathbf{k}$ での重み因子 $\omega_{n \mathbf{k}}$ を乗じた波動関数 の絶対值の 2 乗より

$$
\rho(\mathbf{r})=\sum_{n \mathbf{k}} \omega_{n \mathbf{k}}\left|\psi_{n \mathbf{k}}(\mathbf{r})\right|^{2}
$$

である。 $v_{\mathrm{xc}}$ は交換相関ポテンシャルである。 $\hat{v}_{\mathrm{ion}}^{\mathrm{ps}}$ は擬 ポテンシャルで, $\mathbf{R}$ は実格子ベクトル, $\mathbf{r}_{j}$ は原子の位置 ベクトルである。また, $v_{\text {dip }}$ は, 双極子溶媒分子から電 子に及ぼすポテンシャルである。

我々の遷移金属単結晶面およびその吸着構造の第一原 理計算は実験結果とよく一致することを既に報告してい る ${ }^{28 \sim 31)}$ 。真空中での白金（111）清浄表面に関する計算 の結果, 表面エネルギー $\left(11 \mathrm{eV} / \mathrm{nm}^{2}\right.$, 実験值 $\left.11 \mathrm{eV} / \mathrm{nm}^{2}\right)$, 仕事関数 $(6.0 \mathrm{eV}$, 実験值 $6.1 \mathrm{eV})$, 表面緩和（表面層 と第 2 層の面間はバルクの+ $1.4 \%$ ，実験值 $1.1 \%$ ）は報 告されている実験結果と良く一致した。

今, 有効局所ポテンシャル $v_{\text {eff }}^{\mathrm{loc}}$ を

$$
v_{\text {eff }}^{\text {loc }}=v_{\text {ion }}^{\text {loc }}+v_{\mathrm{H}}+v_{x c}
$$

で定義する。 $v_{\text {ion }}^{\text {loc }}$ は擬ポテンシャルの局所成分 ${ }^{32)}$ である。 溶液の電極の電子への相互作用は 1 次元であるとする。 表面平行方向で平均化された 1 次元局所有効ポテンシャ ルおよび電子密度は, 逆格子空間で自己無撞着に解かれ た Kohn-Sham 方程式の 3 次元ポテンシャルより

$$
\begin{aligned}
& v_{\text {eff }}^{\text {loc }}(z)=\sum_{G_{z}} v_{\text {eff }}^{\text {loc }}\left(0,0, G_{z}\right) \exp \left(i G_{z} z\right) \\
& \rho(z)=\sum_{G_{z}} \rho\left(0,0, G_{z}\right) \exp \left(i G_{z} z\right)
\end{aligned}
$$

ここで， $G_{z}$ は逆格子ベクトルの表面垂直方向の成分で, 上式において平行方向の成分は $G_{x}=G_{y}=0$ である。電極 上の溶媒（古典的双極子）と電極表面は静電ポテンシャ ルで相互作用するので, 静電ポテンシャルを

$$
v_{\text {elst }}(z)=v_{\text {eff }}^{\text {loc }}(z)-v_{\text {xc }}[\rho(z)]
$$

で求める。Fig. 2 に溶媒分子がない時の $v_{\mathrm{eff}}^{\mathrm{loc}}(z), v_{\mathrm{xc}}(z)$, $v_{\text {elst }}(z)$ と $\rho(z)$ を示す。例えば $\mathrm{Al}(111)$ 面のような単 純金属の場合 ${ }^{33)}, 1$ 次元電子密度 $\rho(z)$ は金属内でほぼ 一定となり jellium モデルが良い近似となるが, Pt (111) 面の場合は原子周りに局在した d 軌道のため, jellium モデルは良い近似にはなり得ない。表面から長距離離れ た場所では, 有効ポテンシャルは漸近的に鏡像ポテンシ ヤルー1/zに近づくはずであるが, LDA の近似によりよ り早くゼロに減衰する。電極近傍にある溶媒の感じる静 電ポテンシャルは同様に早く減衰するが, $z=d_{s}$ におい ても $k_{\mathrm{B}} T$ に比べ十分大きい。電極上の $0.2-0.3 \mathrm{~nm}$ の所 で, 電場は $10^{10} \mathrm{~V} / \mathrm{m}$ にもなることをここでは強調して おきたい。

電極と溶媒の相互作用は

$$
v_{m s}= \begin{cases}\infty, & |z|<0 \\ -\frac{\mu}{e} \frac{d v_{\mathrm{elst}}(z)}{d z} \cos \theta, & |z|>0\end{cases}
$$

ここで $\theta$ は溶媒の双極子ベクトルと表面法線のなす角 である。溶媒間の相互作用は双極子-双極子相互作用で 


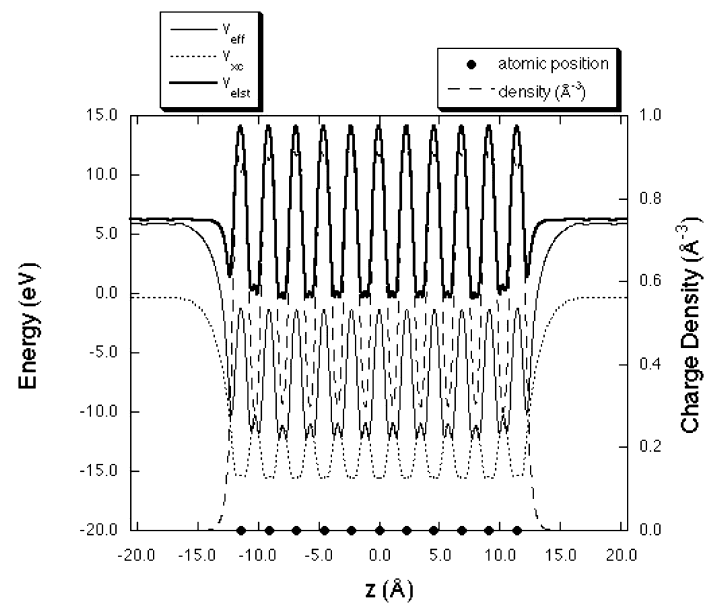

Fig. $2 x y$-averaged effective local (solid line), exchangecorrelation (dotted line), electrostatic potential (thick solid line), and pseudo-valance-charge (dashed line) of $\operatorname{Pt}(111) 11$ layer slab without solvent molecules. The atomic positions of platinum ion are shown in the closed circle.

あり, 短距離の所での反発を直径 $d_{s}$ を持つ剛体球で近 似した。積分方程式論は成書 ${ }^{34}$ に詳しいので省略するが, 溶媒の多体の相互作用は積分方程式論の一つである RHNC 法を用いた ${ }^{15)}$ 。溶媒のバルク密度は, $\rho_{s}{ }^{*}=\rho_{s} d_{s}^{3}=$ 0.7 に, 双極子モーメントは $\mu^{*}=\mu /\left(d_{s}^{3} k_{\mathrm{B}} T\right)^{1 / 2}=\sqrt{3}$ に, 比誘電率は $\varepsilon \sim 50$ とした ${ }^{* * *}$ 。

第一原理計算で得られた静電ポテンシャル $v_{\text {elst }}(z)$ を 用いて表面近傍での液体の密度, 配向を求め, 溶媒の配 置, 配向から双極子溶液（双極子ポテンシャル）と電子 との相互作用 $v_{\text {dip }}(z)$ の大きさを決定した")。この双極 子ポテンシャルを取り入れることにより金属側の電子が 感じる電場は更新され，さらにその場を使って溶液側の 計算を行うことをくり返して, 自己無撞着場を決定し た ${ }^{15)}$ 。表面平行方向に平均化した電子の電荷分布の自己 無撞着な計算結果を Fig. 3 に示す。電荷密度は金属イオ ンを電子原子レベルで扱ったために金属内で強く振動し ている。液体の存在により金属表面から液側に向かって 電子がさらに浸みだしている様子が Fig. 3 の $\Delta \rho$ より明 確である。溶液側の構造を以下に議論する。電極 $(\mathrm{m})-$ 溶媒（s）間の対分布関数 $g_{m s}$ を以下のように展開する。

$\overline{* * *}$ ここでの理論解析において, 溶媒の密度は $\rho=3.2 \times 10^{28}$ 分子 $/ \mathrm{m}^{3}$, 双極子モーメントは $1.65 \mathrm{D}$ であり, 溶媒とし て水を想定している。水の $300 \mathrm{~K}$ での密度は $\rho=3.3 \times 10^{28}$ 分子 $/ \mathrm{m}^{3}$, 水分子の双極子モーメントは $1.86 \mathrm{D}$, 誘電率は 78 である。また, 酸素の半径は $0.14 \mathrm{~nm}$, 水分子中での $\mathrm{OH}$ 間の距離は $0.0957 \mathrm{~nm}$ である。

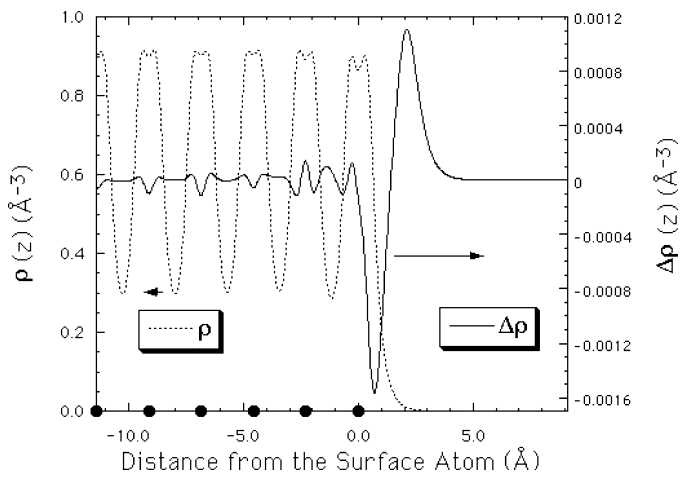

Fig. 3 Electron density profile for $\mathrm{Pt}(111) /$ liquid interface. The self-consistent density profile $\rho_{s c f}$ is shown in the dotted line and the density change $\Delta \rho\left(\equiv \rho_{s c f}-\rho_{\text {vac }}\right.$, where $\rho_{\text {vac }}$ is the density in the vacuum case) caused by the presence of the liquid is shown in the solid line. The atomic positions of platinum are shown in solid circles.

$$
g_{m s}=\sum_{n}(-1)^{n} g^{0 n n}(z) P_{n}(\cos \theta)
$$

ここで, $\theta$ は双極子ベクトルと表面垂線のなす角, $P_{n}$ $(\cos \theta)$ は Legendre 多項式である。 $g^{000}$ は換算動径分布 関数, $g^{011}$ は双極子の配向に関した分布関数に対応し ${ }^{15)}$, 溶媒配向の平均と以下の関係がある。

$$
\langle\cos \theta\rangle=-\frac{g^{011}(z)}{3 g^{000}(z)}
$$

Fig. 4 に実線で示した固液界面での溶媒分子の動径分布 $g^{000}$ は金属界面がない（電場のない）単なる剛体壁（破 線）の密度分布と異なり，より界面近傍に溶媒分子が近 づいたことを示している。（1）吸着層に対応する顕著な 3 つのピークの数およびその位置, (2) 第一ピーク層の 面密度（バルクの密度に比較して約 2 倍）は, Pt (111)| 水溶液界面に対して得られている実験結果 ${ }^{22}$ あるいはよ り詳しい解析がなされた $\mathrm{Ag}(111) \mid$ 水溶液界面系（電極 が負に帯電した時バルクの 1.4 倍, 正に帯電した時 2.3 倍) ${ }^{20,21)}$ を良く再現した ${ }^{* * * *}$ 。

Fig. 5 に示すように界面では, 溶媒分子がもつ双極子 (孤立水分子の場合酸素から両水素の重心に向かって

\footnotetext{
**** Toney $ら^{20,21) の ~} \mathrm{Ag}(111)$ 電極の場合を除いて電極上の 溶媒の構造の実験結果はほとんど得られてない。Tidswell らのPt(111) 電極の場合溶媒構造は十分に決定されてい ない22)。ただし, Toney ら20,21)の結果において, 特に電 極が正に帯電した時, 第一ピークに相当する表面水密度 は過大評価しているのではないかというのが定説になり つつあるようだ。実験の分解能が良くないために起こつ た artifactで, 実際にはさらに 2 本のピークがあるとの

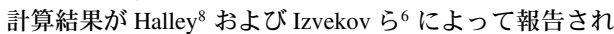
ている。UHV-STM の測定においても ice-like bilayer か ら融解時表面の密度は若干増えるだけであると報告され ている24)。
} 


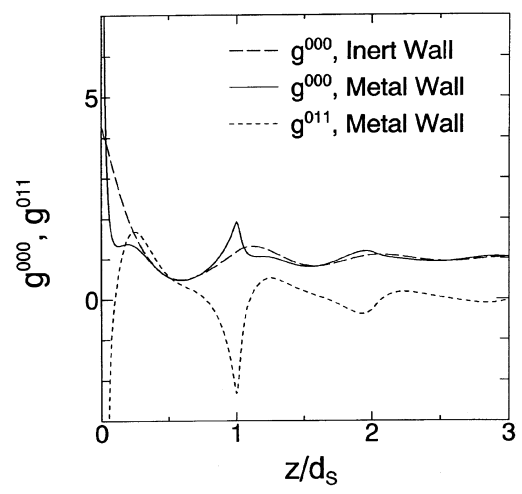

Fig. 4 Self-consistent reduced density profile $g^{000}$ and projection $g^{011}$ near the metal wall are shown as the function of the distance from the surface. The distance from the surface is scaled by the dimeter of the hard sphere in the figure. $g^{000}$ near the inert wall is also shown. $g^{011}$ near the inert wall is zero at all separations. The values of $g^{000}$ (Inert Wall), $g^{000}$ (Metal Wall), and $g^{011}$ (Metal Wall) at $z / d_{s}=0$ are 4.28, 29.94 , and -71.49 , respectively.

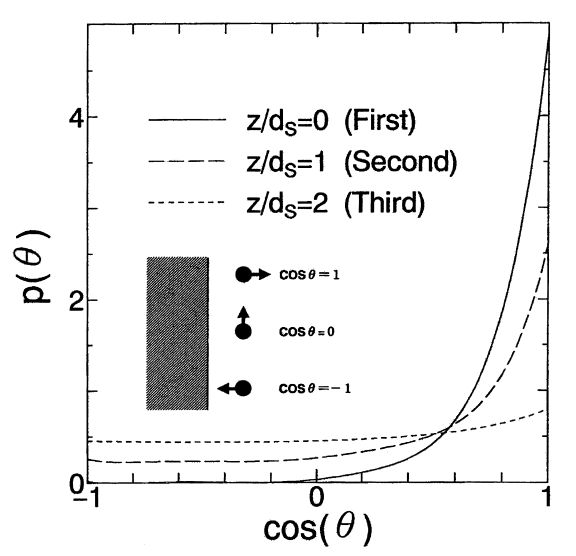

Fig. 5 Self-consistent orientational probability densities $p(z, \theta)$ for dipole vectors at $z / d_{s}=0,1$, and 2 (the first, second, and third layers, respectively).

$1.84 \mathrm{D}=6.13 \times 10^{-30} \mathrm{C} \mathrm{m}$ の双極子がある。）はその向き を界面から外側に向けて配向した。この配向秩序により 溶媒分子は強い引力を金属から感じ, 電場のない場合の 剛体壁に比べより密な溶媒層を形成した。界面からさら に離れるに従い急速にバルクでのランダム配向, 密度に 近づく。Ataka らは赤外分光により $\mathrm{Au}$ (111) 面上の水 分子の配向を明らかにした ${ }^{23)}$ 。ゼロ電荷電位附近で, 電 極表面第一層の水分子は水素結合ネットワークを保持し ようとして水分子はその双極子を表面平行方向にむけて いると報告している。我々のモデルでは, 溶媒分子間の 水素結合的な相互作用は考慮されてないために直接の比

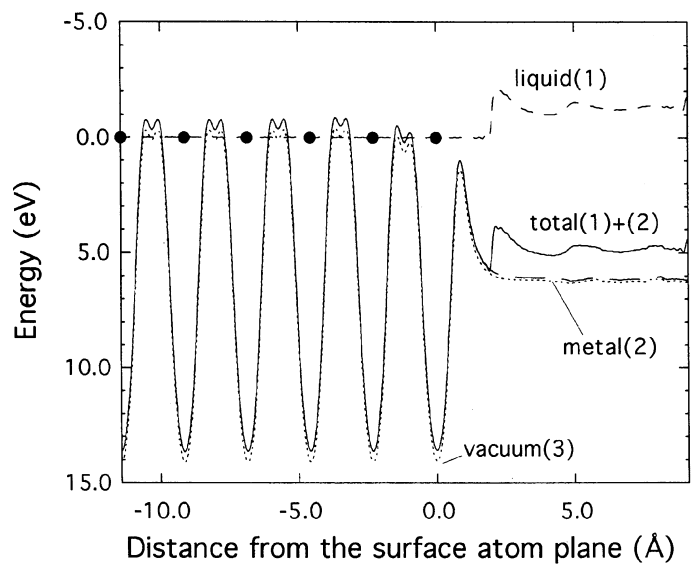

Fig. 6 The electrostatic potential of the Pt(111)/liquid surface. Note that the energy axes are scaled reverse in order to compare the conventional electric potential. The total electrostatic potential (solid line) is the sum of the contributions from the liquid part [dashed line (1)] and the metal part [long-dashed line (2)]. The electrostatic potential for the $\mathrm{Pt}(111)$ /vacuum system is shown in the dotted line (3).

較はできないが, 最近の Izvekov ら6)による $\mathrm{Ag}(111) \mid$ 水 溶液系の ab-initio 分子動力学計算では, 酸素を電極側に して双極子は表面垂直に対して 60 度の角度をもつ水分 子が一番多く分布していると報告している。

固体真空表面, 固液界面を横切る静電ポテンシャルを Fig. 6 に示す。ポテンシャルは金属系を電子原子レベル で扱っているため金属内で強く振動している。全ポテン シャル（1）＋（2）は金属（2）と液体（1）の部分の和で ある。液体が存在すると金属のポテンシャルドロップに 対する寄与 (2)-（3）は金属がない場合と比べて $0.37 \mathrm{eV}$ 大きくなった。これは双極子ポテンシャルが電子をさら に界面外側に引き出すことと一致する。溶液の存在によ る界面をよぎる総計のポテンシャルドロップ(1)+ (2) (3) は, $0.94 \mathrm{eV}$ 減少している。In-situ 電気化学 STM に よるトンネル電流の tip 位置依存性から, 見かけのポテ ンシャル障壁は, 真空の時に比べて固液界面では（数 $\mathrm{meV}$ から $2 \mathrm{e} \mathrm{V})$ 減少することが報告されている。もし, 電極の電子ポテンシャルが溶媒の有無にあまり依存しな いなら，障壁の高さが減少することはポテンシャルドロ ップを引き起こすことに相当する。分子動力学計算では, このポテンシャルドロップは 0.2-0.3 V であると報告さ れている ${ }^{35)}$ 。我々の求めた值が過大評価しているのは, 溶媒に水素結合の影響が入っておらず，より強く電極の 電子のしみ出しが作るポテンシャルに影響を受けたため であると考えられる。

金属の第一原理計算と RHNC 法との結合の自己無撞 
着な計算はここで述べた場合にだけ限られたものではな いということを指摘したい。（1）より洗練された水のモ デル，（2）電解質イオンの導入，（3）より現実的な金属水，（4）金属一イオン相互作用の考慮へも容易に拡張す ることが可能である。さらには，(5）表面の原子レベル での凹凸の影響（例えば Step），(6）電極に電位を与え た時の影響，（7）金属表面構造の変化，（8）電荷容量, （9）水分子の吸着の量子力学的効果，（10）その電位依 存性による水の解離，水素発生，酸化等の化学反応等多 くのことを今後解決していく必要がある。

\section{4. 帯電した $\mathrm{Au}(111)$ 面上の硫黄の吸着}

これまでは，帯電した電極表面については取り扱わな かった。以下は, 溶媒分子は存在しないが带電した金属 表面およびその吸着エネルギー変化について報告す る ${ }^{36)}$ 。Andreasen らは ${ }^{37 \sim 41)}, \mathrm{Au}(111)$ 上の硫黄原子の吸 着組成・構造の電位依存性を報告している。被覆度 $2 / 3$ の $\mathrm{S}_{8}$ 構造から電位を $\mathrm{pzc}$ から約 $0.4-0.5 \mathrm{~V}$ 負な電位にす ると, 被覆率 $1 / 3$ の $(\sqrt{3} \times \sqrt{3})$ R $30^{\circ}$ に可逆的に相変 化する。この相変化が (1) 電極の帯電によるものか (2) 溶媒分子を含めた電気化学的な影響によるかを明らかに するため帯電の影響による変化をここでは報告する。

帯電の方法は既に報告されている方法を用いた ${ }^{42 \sim 44)}$ 。 即ち, 仮想的な電荷シート（ガウス分布させると逆格子 空間で扱いやすい。）を金属スラブの中間に置く。Fig. 7 に周期セルと仮想電荷シートの配置図を示す。仮想的な 電荷が作る電場は金属表面の電子によって完全に遮蔽さ れる。 $\mathrm{Au}$ (111) 面上での遮蔽されたポテンシャル断面 図は Fig. 8 のように，また遮蔽された電子の再配置は Fig.9のようになる。Fig. 8 では, 仮想的な電荷シート の電荷がゼロの時と負の電荷 $\left(\sigma=-0.264 \mathrm{C} / \mathrm{m}^{2}=-\sigma_{\mathrm{M}}\right)$ を置いた時の有効ポテンシャルの差をとった図である。 ここで， $\sigma ， \sigma_{\mathrm{M}}$ は電荷シートおよび金属の表面電荷密 度である。電子のポテンシャルは仮想的な電荷シートか ら金属表面に向かってほぼ直線的に減少し，5層の金属 スラブ内では，ポテンシャルの変化はほぼゼロであるこ とがわかる。直線の部分から求めた電場は電磁気学から

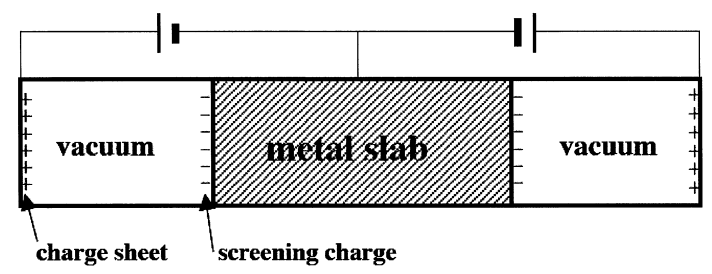

Fig. 7 Schematic diagram of the electrified surface used in the slab model calculation.
得られた結果

$$
E z=\frac{\sigma}{2 \varepsilon_{0}}
$$

に一致する。ここで， $\varepsilon_{0}$ は真空の誘電率である。電磁 気学の教科書では, 遮蔽電荷は表面にデル夕関数的に分 布していると近似しているが，微視的に見れば有効ポテ ンシャルの小さい表面 $\mathrm{Au}$ 原子の外側（矢印で screeningcharge と示したところ）に多く存在し，また遮蔽電荷は 表面平行方向は必ずしも均一ではない状態で分布してい

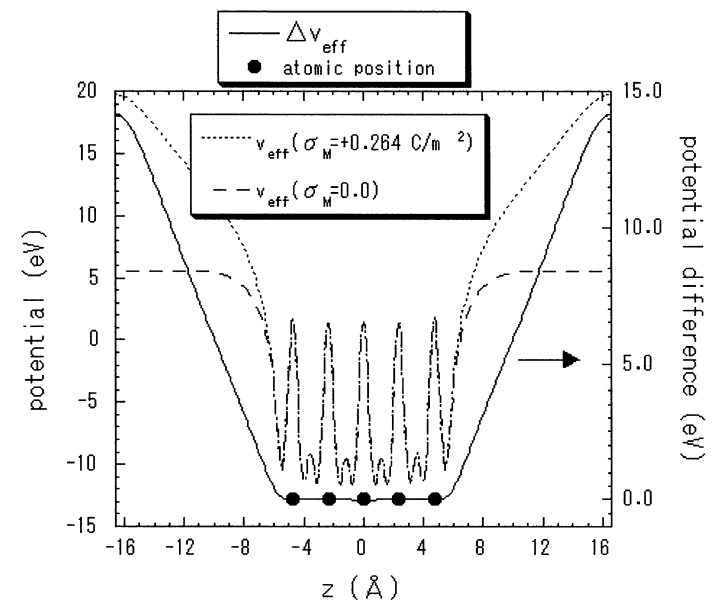

Fig. 8 Screened potential profile $\Delta v_{\text {eff }}(z)$ for $\mathrm{Au}(111)$ surface. The difference $\Delta v_{\text {eff }}(z)$ is defined by $\Delta v_{\text {eff }}(z)=$ $v_{\text {eff }}\left(z, \sigma_{\mathrm{M}}\right)-v_{\text {eff }}\left(z, \sigma_{\mathrm{M}}=0\right)$. The effective electron potentials for $\sigma_{\mathrm{M}}=0.0$ (broken line) and $\sigma_{\mathrm{M}}=+0.264$ $\mathrm{C} / \mathrm{m}^{2}$ (dotted line) are also shown.

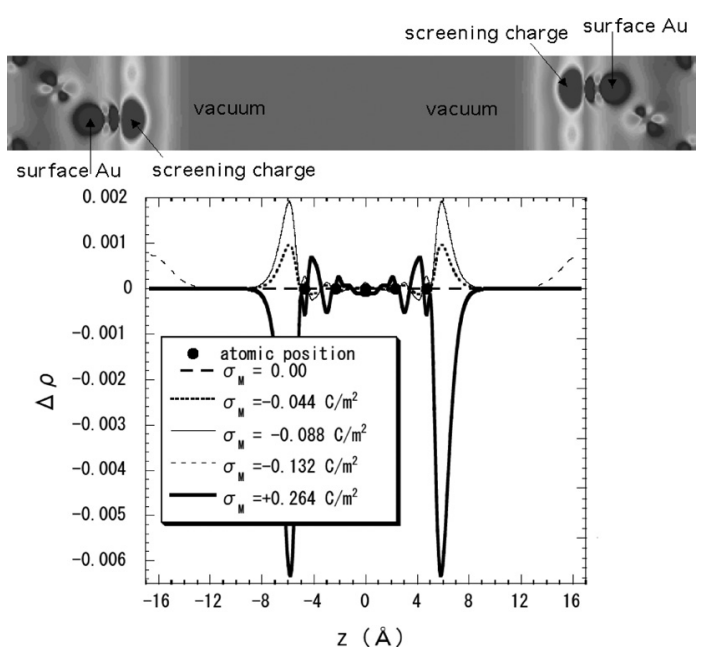

Fig. 9 Screening charge distribution for $\mathrm{Au}(111)$ surface. 2D map for $\sigma_{\mathrm{M}}=-0.044 \mathrm{C} / \mathrm{m}^{2}$ (the upper figure) and surface-averaged screening charge profile. 
Table 1 Calculated physical properties for $\mathrm{Au}(111)-(\sqrt{3} \times \sqrt{3}) \mathrm{R} 30^{\circ}-\mathrm{S}$ structure.

\begin{tabular}{|c|c|c|c|c|c|c|}
\hline \multirow{2}{*}{$\begin{array}{l}\text { Adsorption } \\
\text { Site }\end{array}$} & \multirow{2}{*}{$\begin{array}{c}\text { Adsorption } \\
\text { Energy } \\
\text { (eV/S atom) }\end{array}$} & \multirow{2}{*}{$\begin{array}{c}\text { Workfunction } \\
\text { Change } \\
(\mathrm{eV})\end{array}$} & \multicolumn{3}{|c|}{ Interlayer Distance $(\AA)$} & \multirow{2}{*}{$\begin{array}{l}\delta Q_{\mathrm{s}} \\
\text { (e) }\end{array}$} \\
\hline & & & S-Au 1 & Au 1-Au 2 & Au 2-Au 3 & \\
\hline FCC & -4.950 & +0.22 & 1.60 & 2.38 & 2.38 & -0.15 \\
\hline $\mathrm{HCP}$ & -4.797 & +0.24 & 1.65 & 2.39 & 2.36 & \\
\hline ATOP & -3.440 & +0.85 & 2.23 & 2.41 & 2.39 & -0.02 \\
\hline
\end{tabular}

Table 2 Calculated physical properties for $\mathrm{Au}(111)-(1 \times 1)-\mathrm{S}$ structure.

\begin{tabular}{|c|c|c|c|c|c|c|}
\hline \multirow{2}{*}{$\begin{array}{l}\text { Adsorption } \\
\text { Site }\end{array}$} & \multirow{2}{*}{$\begin{array}{c}\text { Adsorption } \\
\text { Energy } \\
\text { (eV/S atom) }\end{array}$} & \multirow{2}{*}{$\begin{array}{c}\text { Workfunction } \\
\text { Change } \\
(\mathrm{eV})\end{array}$} & \multicolumn{3}{|c|}{ Interlayer Distance $(\AA)$} & \multirow{2}{*}{$\begin{array}{l}\delta Q_{\mathrm{s}} \\
\text { (e) }\end{array}$} \\
\hline & & & S-Au 1 & $\mathrm{Au} 1-\mathrm{Au} 2$ & $\mathrm{Au} 2-\mathrm{Au} 3$ & \\
\hline FCC & -3.780 & +0.11 & 2.12 & 2.36 & 2.37 & -0.13 \\
\hline $\mathrm{HCP}$ & -3.788 & +0.14 & 2.12 & 2.35 & 2.37 & -0.12 \\
\hline ATOP & -3.968 & +0.19 & 2.40 & 2.35 & 2.37 & -0.04 \\
\hline
\end{tabular}

る。この分布の違いが，吸着子との相互作用に影響を与 える可能性がある。金属表面を負に強く帯電させると, 金属表面から仮想的な電荷シートへの電子の移動が (Fig. 9 で $\sigma_{\mathrm{M}}=-0.132 \mathrm{C} / \mathrm{m}^{2}$ より負電荷密度の場合) あ り, 注意を要する。

電荷シートがないときの $(\sqrt{3} \times \sqrt{3}) \mathrm{R} 30^{\circ}$ 構造の吸着 エネルギー, 清浄表面からの仕事関数変化, 表面緩和, 硫黄原子への電荷移行量を Table 1 に示す。FCC サイト が最も安定であることは実験結果 ${ }^{37 \sim 41)}$ と一致した。 $\mathrm{S}_{8}$ 構造は下地の金属と commensurate の関係にないので, 仮想的な $(1 \times 1)$ 構造を仮定して計算を行った。帯電し ていない時の $(1 \times 1)-\mathrm{S}$ 構造の結果を Table 2 に示す。

仮想的な電荷シートは人工的に挿入したので, 系の全 エネルギーは物理的な意味を持たない。ただし，2つの 系で同じ電荷シートをもつ場合, その全エネルギーの差 は, 電荷シートの自己エネルギー等の付加的な部分がキ ヤンセルするため, 帯電した 2 つ系の表面エネルギー の差として定義できる。今, $\mathrm{Au}(111)$ 面上の硫黄の吸 着エネルギーの帯電による変化を以下の式で定義する。

$$
\begin{aligned}
\Delta E_{\mathrm{ad}}\left(\sigma_{\mathrm{M}}\right)= & {\left[E\left(\sigma_{\mathrm{M}} ; \mathrm{S} \text { adsorption system }\right)\right.} \\
& -E\left(\sigma_{\mathrm{M}} ; \mathrm{Au}(111) \text { system }\right) \\
& -2 E(\mathrm{~S} \text { atom })] / 2
\end{aligned}
$$

ここで, $\sigma_{\mathrm{M}}$ は金属表面の表面電荷密度, 上式右辺第一項 は電極表面が $\sigma_{\mathrm{M}}$ に帯電した時の金-硫黄系スラブの全 エネルギー, 第二項は $\mathrm{Au}$ (111) 面が帯電した時のスラ ブの全エネルギーである。 $E$ (S atom) は硫黄 (擬) 原子 の全エネルギーである。表面が 2 つあるので, 2 の係数 がついている。 Au (111) - $(\sqrt{3} \times \sqrt{3}) \mathrm{R} 30^{\circ}-\mathrm{S}$ 構造と $(1 \times 1)$ 構造について $\Delta E_{\text {ad }}\left(\sigma_{\mathrm{M}}\right)$ を計算し, 帯電していない時の $\Delta E_{\text {ad }}(0)$ をゼロにした $\Delta \Delta E_{\text {ad }}$ を Fig. 10 に示す。Fig. 10 は, 電極を帯電させると, 電荷の符号によって非対称で

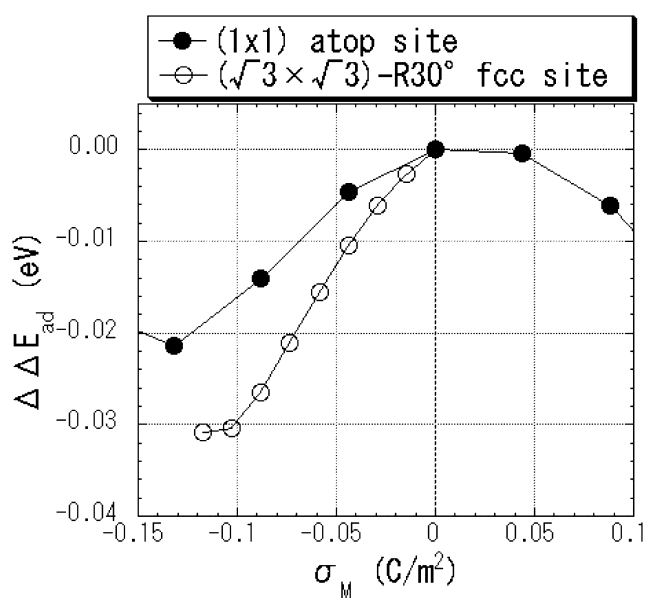

Fig. 10 Electrocapillary curves of $\mathrm{Au}(111)-(\sqrt{3} \times \sqrt{3}) \mathrm{R}$ $30^{\circ}-\mathrm{S}$ structure and $\mathrm{Au}(111)-(1 \times 1)-\mathrm{S}$ structure.

はあるが吸着エネルギーは安定化することを示してい る。実験結果は, 電極の電位を負にすることにより高被 覆率の吸着相から低被覆率の $(\sqrt{3} \times \sqrt{3})$ R $30^{\circ}$ 相に変化 している。Fig. 10 では低被覆率の $(\sqrt{3} \times \sqrt{3})$ R $30^{\circ}$ 相 が $(1 \times 1)$ 相にくらべて, 負の帯電に対してエネルギー がより安定化している。このことは実験結果と矛盾しな い。実際は水溶液に脱離していく硫黄を考慮しなくては ならないので, 帯電状態だけで実駼結果を説明すること はできないが, 傾向は矛盾しないことが明らかとなった。

\section{5. を め}

以上の白金上の溶液構造と金表面の帯電による吸着エ ネルギーの 2 例を電極の第一原理計算として紹介した が, 現実の電気化学系との間には大きな隔たりがあるこ とは確かである。よりミクロスコピックな観点にたった 
分光実験を含む実験結果の積み重ねと理論の改良の突き 合わせによって, 既に理解しつくされたと考えられてい る固体表面の電気化学を新たな視点から見直すことがで きるかもしれない。

\section{謝辞}

この研究を行うにあたって, 共同研究者の京都大学工 ネルギー理工学研究所の木下正弘先生, 京都大学大学院 工学研究科の垣内 隆先生, 香港科学技術大学物理学科 の C.T. Chan 先生, Ames 研究所-アイオワ州立大学物理 学科の K.M. Ho 先生, Max-Plank 金属研究所の C. Elsässer 先生に感謝いたします。

\section{文献}

1) P.J. Feibelman, B. Hammer, J.K. N $\phi$ rskov, F. Wagner, M. Scheffler, R. Stumpf, R. Watwe and J. Dumesic: J. Phys. Chem. B 105, 4018 (2001).

2) I. Grinberg, Y. Yourdshahyan and A.M. Rappe: J. Chem. Phys. 117, 2264 (2002).

3) C.P. Ursenbach, A. Calhoun and G.A. Voth: J. Chem. Phys. 106, 2811 (1997).

4) A. Klesing, D. Labrenz and R.A. van Santen: J. Chem. Soc. Faraday Trans. 94, 3229 (1998).

5) S. Izvekov, A. Mazzolo, K. VanOpdorp and G.A. Voth: J. Chem. Phys. 114, 3248 (2001).

6) S. Izvekov and G.A. Voth: J. Chem. Phys. 115, 7196 (2001)

7) 山本雅博: To be published in 電気化学会誌 Q\& A (2003).

8) J.W. Halley, S. Walbran and D.L. Price: "Chemical Physics of the Electrode-electrolyte Interface", vol. 116 of Adv. Chem. Phys. (John Wiley \& Sons, New York, 2001).

9) D.R. Bérard, M. Kinoshita, X. Ye and G.N. Patey: J. Chem. Phys. 101, 6271 (1994).

10) D.R. Bérard, M. Kinoshita, X. Ye and G.N. Patey: J. Chem. Phys. 102, 1024 (1995).

11) M. Kinoshita and D.R. Bérard: J. Comput. Phys. 124, 230 (1996).

12) D.R. Bérard, M. Kinoshita, N.M. Cann and G.N. Patey: J. Chem. Phys. 107, 4719 (1997).

13) J. Schnitker and P.J. Rossky: J. Chem. Phys. 86, 3462 (1987).

14) M. Yamamoto and M. Kinoshita: Chem. Phys. Lett. 274, 513 (1997).

15) M. Yamamoto, M. Kinoshita and T. Kakiuchi: Electrochim. Acta 46, 165 (2000).

16) A. Kovalenko and F. Hirata: J. Chem. Phys. 110, 10095 (1999).

17) A. Kovalenko and F. Hirata: J. Mol. Liq. 90, 215 (2001).

18) L. Hedin and B.I. Lundqvist: J. Phys. C 4, 2064 (1971).

19) C. Elsässer, N. Takeuchi, K.M. Ho, C.T. Chan, P. Braun and M. Fähnle: J. Phys.-Condes. Matter 2, 4371 (1990).

20) M.F. Toney, J.N. Howard, J. Richer, G.L. Borges, J.G. Gordon, O.R. Melroy, D.G. Wiesler, D. Yee and L.B. Sorensen: Nature 368, 444 (1994).

21) M.F. Toney, J.N. Howard, J. Richer, G.L. Borges, J.G. Gordon, O.R. Melroy, D.G. Wiesler, D. Yee and L.B. Sorensen: Surf. Sci. 335, 326 (1995).

22) I.M. Tidswell, N.M. Markovic and P.N. Ross: J. Electroanal. Chem. 376, 119 (1994).

23) K. Ataka, T. Yotsuyanagi and M. Osawa: J. Phys. Chem. 100, 10664 (1996).

24) M. Morgenstern, J. Müller, T. Michely and G. Comsa: Z. Phys. Chemie. 198, 43 (1997).

25) H. Siegenthaler: "STM in Electrochemistry", vol. II of Scanning Tunnelling Microscop (Springer, Berlin, 1992) Chapter 2, p. 7.

26) A. Peremans and A. Tadjeddine: J. Chem. Phys. 103, 7197 (1995).

27) N.D. Lang and W. Kohn: Phys. Rev. B 1, 4555 (1970).

28) M. Yamamoto, C.T. Chan and K.M. Ho: Phys. Rev. B 50, 7932 (1994).

29) M. Yamamoto, C.T. Chan, K.M. Ho and S. Naito: Phys. Rev. B 54, 14111 (1996).

30) M. Yamamoto, C.T. Chan, K.M. Ho, M. Kurahashi and S. Naito: Phys. Rev. B 53, 13772 (1996).

31) M. Yamamoto, M. Kurahashi, C.T. Chan, K.M. Ho and S. Naito: Surf. Sci. 387, 300 (1997).

32) M.L. Cohen and V. Heine: "The Fitting of Pseudopotentials to Experimental Data and their Subsequent Application", vol. 24 of Solid State Physics (Academic, New York, 1970) p. 37.

33) J.R. Chelikowsky, M. Schlüter, S.G. Louie and M.L. Cohen: Solid State Commun. 17, 1103 (1975).

34) J.-P. Hansen and M.I.R.: "Theory of Simple Liquids 2nd ed." (Academic, London, 1990).

35) H. Spohr: "Computer Simulation of Electrochemical Interfaces", vol. 6 of Advances in Electrochemical Science and Engineering (Wiley-VCH, Weinheim, 1999) p. 1.

36) M. Yamamoto and C.T. Chan: To be submitted.

37) G. Andreasen, C. Vericat, M.E. Vela and R.C. Salvarezza: J. Chem. Phys. 111, 9457 (1999).

38) C. Vericat, G. Andreasen, M.E. Vela and R.C. Salvarezza: J. Phys. Chem. B 104, 302 (2000).

39) H. Martin, C. Vericat, G. Andreasen, A.H. Creus, M.E. Vela and R. C. Salvarezza: Langmuir 17, 2334 (2001).

40) C. Vericat, M.E. Vela, G. Andreasen, R.C. Salvarezza, L. Vazquez and J.A. Martin-Gago: Langmuir 17, 4919 (2001).

41) C. Vericat, M.E. Vela, G.A. Andreasen, R.C. Salvarezza, F. Borgatti, R. Felici, T.L. Lee, F. Renner, J. Zegenhagen and J. A. Martin-Gago: Phys. Rev. Lett. 90, 302 (2003).

42) C.L. Fu and K.M. Ho: Phys. Rev. Lett. 63, 1617 (1989).

43) K.P. Bohnen and D.M. Kolb: Surf. Sci. 407, L 629 (1998).

44) J.G. Che and C.T. Chan: Phys. Rev. B 67, 125411 (2003). 